\title{
Public Bureaucracy from the Perspective of the State Budget
}

\author{
Hana Markova*
}

\begin{abstract}
* Prof. JUDr. Hana Marková, CSc., Professor of Financial Law and Financial Science, Department of Financial Law and Financial Science, Faculty of Law, Charles University, the Czech Republic. The author specialises in tax law and budgetary law. She is the author or co-author of more than 10 books and 70 reviewed articles. She is a member of the Centre of Information and Organization of Public Finances and Tax Law Research in Central and Eastern Europe. This paper has been elaborated within the programme "PROGRES Q02 - Publicization of Law in the European and International Context" which is realized in 2019 at the Faculty of Law of the Charles University. ORCID: 0000-0002-0204-4571. (e-mail: markova@prf.cuni.cz)
\end{abstract}

\begin{abstract}
The state covers needs that are necessary for the running of the state from its revenues (most often from tax revenues). If territorial self-governments exist, certain public goods are funded from territorial budgets. The state contributes concurrently to territorial self-governing units to the performance of delegated powers - most often through subsidies. The contribution to the performance of state administration can be considered one of these subsidies. At all levels of government, the effect of bureaucracy is manifested in the form of coercion consisting of the use of "normative" power and "rewarding" power.
\end{abstract}

Keywords: state budget; public goods; contribution to the performance of delegated power; bureaucracy

\section{State Budget and its Functions}

The original narrow fiscal role of the state budget, that is based on the classical theory of political economy, began to change at the end of the $19^{\text {th }}$ century. Regarding the earlier theoretical conception and the practical application of public finance the state budget was a tool for amassing taxes. The practice, however, tends towards the economic concept of the state budget on the basis of the development of the new theoretical conceptions. This conception of the state budget is reflected in the fact that the original term "state budget" has a wider content in comparison to previous definitions that consisted of the collection of taxes and the reimbursement of narrowly defined state expenditures. Budgets are entrusted with other than just fiscal targets.

The state budget begins to fulfil the allocation role, i.e. it begins to influence the allocation of factors of production according to the needs of economic development, and concurrently to apply its distributional function which consists in influencing the income situation of the productive sphere and of the population. Together with the growth of expenditure of the state, the budget revenues have to increase. The possibility of hindering 
or eliminating economic crises is attributed to the expenditures of the state budget. However, this effect of the state budget has been greatly overestimated in the last decades and current practice has corrected some of the theoretical starting points in this field.

Even today, the state budget is the basic financial plan of the state that is approved on a yearly basis in the form of an act and serves to amass the financial resources of society and to irrevocably allocate these resources. The resources are then allocated on the basis of the determination of the tasks that are determined especially for the financial covering of the state functions (i.e. fiscal purpose) and for the influencing of the national economy (nonfiscal purpose).

The state budget is entrusted with the particularly important role of amassing and re-distributing that part of the gross domestic product that is intended for the needs of society. The function of the state budget is thus not only economic but also political. Depending on the amount of financial resources collected and, in particular, on the purposes (including their priority arrangement) for which these resources are spent, the character of the state policy could be considered.

The process of reproduction to which the state budget serves is currently not only recognised from a narrow point of view of material production but also as an activity aimed at the development of the immaterial needs of a particular society and related relationships. Further changes of this process could be expected regarding the introduction of robotisation. Interests of society (i.e. the material aspect of the state budget) are also secured from the procedural point of view, i.e. through the competencies of the state bodies in which the approval of legal regulation of budgets and the control of their application (fulfilment of their requirements) is vested. The budget process represents the annual concretisation of state policy for the following year and the state final account discussed after the end of the budget period represents the assessment of the state policy.

Regarding the economic effect of the state budget, it can be stated that the allocation, distribution and control and register functions of the budget are applied. The distribution and placement of financial resources (the allocation function) in the respective economic spheres represents the essence of the economic impact of the state budget. The state budget is supplemented by other financial plans, however, it does, in comparison with them, carry out the distribution of both monetary and material resources definitively. The distribution (redistribution) function is the actual mission of each budget. This means the redistribution of gross domestic product in respect of the needs of society. Other functions such as control or stimulus functions can be included in the budget functions. These functions represent the possibility to affect the reproduction process by the state budget in various ways and they are therefore considered an instrument of the state's financial policy.

The functions of the state budget are not only economic, but also political. Depending on the amount of financial resources amassed and in particular on the purposes for which they are spent the character of the state's policy can be recognised. Through the state budget, the government can finance certain activities that ensure the essential functions of the state. The government can also affect the economy of territorial self-governing units (especially the amount of subsidies). The budgets of the territorial self-governing units, as well as the budgets of the state funds then perform similar functions as the state budget and form together with the state budget a system of public budgets. 


\section{Public Goods, Their Financing and Bureaucracy}

There are public goods in the economy for which the concentration of resources in the state budget is necessary (e.g. defence, justice) and other goods whose financing seems to be more effective at the level of the territorial budgets. However, there are also public goods where it is possible to finance them through the territorial budgets or budgets of state funds - i.e. these goods can be financed by different public budgets at the same time. Thus, through public budgets, resources are redistributed from resource-generating entities to those that do not generate resources but are an integral part of society. How large the redistribution will be, either among the population groups or between the regions of the state, depends on a number of factors. In particular, it is about the interaction of the principle of solidarity and the principle "everyone for his own" (i.e. non-solidarity). Ensuring a certain standard level of the most important public goods for the entire national territory is essential. It is equally necessary to ensure a certain stabilisation of economic development which is only possible through the central budget. On the other hand, the regional budgets should respect different population preferences.

National public goods are those goods of which the inhabitants of the entire state benefit. These goods include the construction of roads, the regulation of watercourses, etc. This kind of public expenditure is financed by the resources of both municipalities and regions or the state. A specific group of public goods consists of so-called preferred goods when the state decides how certain goods will be consumed, for example, by determining that the municipality or region has to ensure these goods and the citizens have to consume them. For example, the law provides for a certain obligation (e.g. school attendance) and territorial units have an obligation to ensure its realisation. There is a national standard for the goods that are controlled by the government and subsidies are usually provided for the financing of these goods. Such public goods are available to all citizens regardless of their financial situation.

Public goods are provided by territorial units through their budget. However, the state budget is also involved in the financing of these public goods. Expenditure on securing public goods, such as expenditure on security or territorial government, should be covered by tax revenues in respect of their budgetary determination and by transfers from the budgetary system (i.e. subsidies). However, there are also local public goods - those goods that municipalities provide primarily for their inhabitants and that can be measured as regards the consumption and on which user charge can be imposed (e.g. charge paid for the use of water supply for wastewater treatment) to a certain extent.

State administration is built as a tool for satisfying public interests. Between the citizen as the consumer and the official as the administrator of the budget expenditures, there is a chain of mechanisms that effectively guarantee considerable autonomy. The administration of "public goods", which is the actual reason for the existence of the public sector, can be easily manipulated. For example, certain interest groups are able to convince the public administration of the necessity to provide such "public goods" which are beneficial only to such groups. The demand for "public goods" is often generated by bureaucracy itself with the support of various regulations and decrees. 
Bureaucracy is a term that can determine a hierarchical organizational form of government. It had been known since antiquity but its newer form has occurred in connection with the development of the so-called welfare state. Bureaucracy exercises its power in several underlying ways. These ways are:

- Coercion that consists, for example, of repeated inspections, requiring information and constantly supplementing background material for administrative decisions about fines and regressive measures.

- The use of "normative" power that can be considered to consist in creating a certain prestige of the administrative apparatus which is based on direct determination of the conditions of mutual dialogue with the citizens by such administrative apparatus. The relationship of superiority and subordination of bureaucrats and citizens is not given by the authority of the institution but by the conditions laid down by this superior power.

- The influence of "rewarding" power can be used as a definition for the latent, material and also non-material impact of corruption on the government and decisionmaking of the administrative apparatus.

Although the possibilities for bureaucracy development are numerous in the Czech Republic, it is possible to mention the area of budgetary law in a broad sense. The current budgetary system is linked to the collection of taxes and other compulsory levies on the one hand and, on the other hand, it is linked to the determination of conditions for drawing public funds (in the area of subsidies or public procurement, etc.). A certain cumbersomeness of the Czech system leads to greater demands on ensuring all processes related to selection and drawing of public funds.

\section{State Expenditures on the Exercise of Delegated Powers}

In addition to the public expenditures on public goods, the state contributes to the activities of territorial self-governments that they take over from the state. The state secures by its own resources not only its own activities, but it also contributes to territorial selfgoverning units to the performance of delegated powers. This is done in different ways - most often by various forms of subsidies. One of them is contribution to the performance of state administration.

Contribution to the fulfilment of tasks of territorial self-governments that come under the delegated competence can be described as state budget expenditure determined by a special act (i.e. by the State Budget Act for the relevant year). The State Budget Act determines the total amount of the contributions to all municipalities to the performance of state administration and in the annex to this Act the procedure for determining the amount of the contribution to the performance of state administration provided to individual municipalities is subsequently regulated.

The term contribution expresses the fact that the state only contributes to municipalities and regions to the performance of public administration. Many of the agendas that the regions and municipalities carry out serve not only the state but also these municipalities 
and regions. These agendas, for example, are the issuing of identity cards, the keeping of the population register, as well as other activities regulated by law. The state contribution to the exercise of the delegated power is thus intended to cover a part of the expenses related to the performance of state administration. ${ }^{1}$ This construction is based on the fact that the territorial self-governing units have revenues generated by the agendas, for example, in the form of administrative charges that remain in their budgets. The contribution can also be referred to as a non-purpose subsidy whose form of drawing is not controlled. ${ }^{2}$

The calculation of the contribution to the performance of state administration, i.e. to the delegated competence, is determined differently for the regions, municipalities and Prague. The contribution for the regions is determined by the Ministry of Finance on the basis of the recalculated work time dedicated to performance of the delegated competences that have been determined at the time of the establishment of the regional offices. Determination of the amount and the distribution of the contribution to the regions is not affected by the Ministry of the Interior in any way. However, the situation is different with regard to the distribution of the contribution to the municipalities. The particular act states that "the municipal budget shall bear the expenses associated with the performance of state administration that is vested in the municipality by law". These are, in particular, wage and operating expenses linked to staff employed by state administration.

The contribution is allocated to municipalities on the basis of the size of the municipality and the size of the administrative district of the municipality that is expressed by the number of inhabitants. As regards the municipalities with extended competence, the ratio of the size of the administrative district to the size of the administrative centre itself is important. Both of these parameters are expressed in the number of inhabitants. In the calculation of the contribution, five types of administrative roles of municipalities are considered: basic competence, registry offices, building authorities, municipalities with authorised municipal office, municipalities with extended competence. The total contribution of a particular municipality consists of partial contributions for each relevant role. As regards the contribution, the specific category of cities with a specific status, which represent the agglomeration background of large cities, is considered. ${ }^{4}$

Overall, it can be stated that the state, regional and municipal expenditures are interlinked. Financial transfers ensure the unity of public budgets and concurrently - as the range of activities that are included among public goods get broader - the role of the entities involved in securing the public goods grows and thus, as a rule, the amount of funds that are redistributed between public budgets also grows. The role of bureaucracy does not disappear, but it grows.

\section{Conclusion}

Inability to control its costs forces the public sector to raise taxes. This in turn enables public budgets to inflate. Tax collection and tax defence forces the rest of the economy to focus more on redistribution of existing wealth than on creation of the wealth. Within the Czech public sector there is no internal motive to increase the efficiency of its system. 
Bureaucracy cannot disappear because of its nature. In each system there are functions and activities whose performance is delegated to the higher authorities by the public. The society voluntarily restricts its own sovereignty and freedom of decision and expects the state to be responsible for it. The line of de-bureaucratisation of the state is the reduction of the administrative burden. Fully functional measures need to be taken to concentrate on related agendas, develop functional digitalisation of state administration and to reduce the amount of required information. Transformation of state administration through information and communication technologies must therefore be considered as the overriding task of all political forces. 


\section{References}

1 Act No. 128/2000 Coll., on Municipalities, as amended, in section 62 states: "The municipalities shall receive from the state budget a contribution for the fulfilment of delegated powers." Similarly, Act No. 129/2000 Coll., on Regions, as amended, in section 29 par. 2 states: "The region shall receive from the state budget a contribution for the performance of the delegated power. The amount of the contribution shall be determined by the Ministry of Finance after discussion with the Ministry of the Interior."

2 Until 2002 the allowance was set at a particular rate per 100 inhabitants of the administrative district for municipalities with basic competence, for municipalities with the competence of the registry office, for municipalities with the competence of the building office and the authorised municipal office. Rates were set by the Ministry of Finance.

Between 2003 and 2005 the role of the Ministry of the Interior was to determine (and adjust) the number of posts transferred from district offices that determines the amount of the contribution for municipalities with extended powers. The rate (used for determination of the contribution) for one post was set by the Ministry of Finance. In 2003 the rate was about 334,000 CZK, in 2004 about 351,000 CZK. And in 2005 about 368,000 CZK.

For 2006 the Ministry of the Interior prepared a new methodology for determining the amount of the contribution for municipalities which brought the unification of calculation and introduction of two criteria (the size of the administrative district and the ratio of the size of the centre to the size of the administrative district).

Recently, every year, the Ministry of the Interior proposes a method of allocating funds to municipalities that are intended to cover state administration carried out by municipalities.

3 Section 9 par. 1 (c) of the Act No. 250/2000 Coll., on Budgetary Rules of Territorial Budgets, as amended.

4 For the year 2018 the total amount of funds transferred to the performance of delegated power by municipalities was increased by $5 \%$ and similarly it should be increased in 2019 and 2020 (this is based on the budgetary outlook for those years). The same percentage increase was made in 2017. The parameters for the increase of funds for regions and the capital city Prague are the same as for municipalities. For the year 2018, the part of the contribution to the delegated competence that consists of flat-rate payments is being enforced. Such payments try to take into account the frequency of selected agendas at particular offices. The elements of transparency and targeting in compliance with the fulfilment of the Strategic Framework of Public Administration Development are strengthened. For more detail, see David Sláma, Novinky ve financování přenesené působnosti obcí v roce 2018, Obec a finance č.5/2017. 